DOI: https://doi.org/10.24127/ajpm.v9i3.2925

\title{
PENGEMBANGAN MODUL AJAR BERBANTUAN TEKNOLOGI UNTUK MENGEMBANGKAN KECAKAPAN ABAD 21 SISWA
}

\author{
Fabiana Dini Prawingga Nesri ${ }^{1}$, Yosep Dwi Kristanto ${ }^{2^{*}}$ \\ ${ }^{1,2^{*}}$ Pendidikan Matematika, Universitas Sanata Dharma Yogyakarta, Indonesia \\ *Corresponding author. Universitas Sanata Dharma, Yogyakarta, Indonesia. \\ E-mail: $\quad$ dinifabiana052@gmail.com ${ }^{1)}$ \\ yosepdwikristanto@usd.ac.id ${ }^{2 *}$
}

Received 09 July 2020; Received in revised form 13 September 2020; Accepted 23 September 2020

\begin{abstract}
Abstrak
Tujuan penelitian ini adalah untuk mengembangkan modul ajar berbantuan teknologi yang valid, praktis, dan efektif untuk mengembangkan kecakapan abad 21 siswa pada materi lingkaran. Metode yang digunakan pada penelitian ini adalah penelitian dan pengembangan. Proses pengembangan modul dilaksanakan dengan menggunakan model pengembangan ADDIE (Analysis, Design, Development, Implementation, Evaluation). Tahap analisis meliputi analisis kebutuhan sumber belajar, kurikulum dan materi. Tahap perancangan meliputi pembuatan kerangka modul, penentuan tata letak dan buku referensi, serta penyusunan instrumen penilaian modul. Tahap pengembangan meliputi pengembangan modul, validasi ahli, dan revisi modul. Tahap implementasi adalah tahap uji coba modul yang telah divalidasi dan direvisi kepada siswa. Tahap evaluasi adalah tahap menganalisis kelebihan dan kelemahan modul yang telah diujicobakan. Kualitas modul ditentukan oleh tiga kriteria yaitu validitas, kepraktisan dan keefektifan. Modul ini dinyatakan valid berdasarkan penilaian dari ahli materi dengan rata-rata sebesar $87 \%$ dan penilaian dari ahli media dengan rata-rata sebesar $83 \%$. Selain itu modul dinyatakan praktis berdasarkan hasil kuesioner respon siswa, yaitu dengan rata-rata sebesar $74 \%$. Selanjutnya berdasarkan hasil wawancara dengan guru, modul ini efektif membantu siswa memahami materi lingkaran khususnya topik persamaan lingkaran dan memiliki potensi untuk meningkatkan kecakapan abad 21. Berdasarkan hasil tersebut dapat disimpulkan bahwa modul ajar cetak berbantuan teknologi yang dikembangkan valid, praktis, dan efektif.
\end{abstract}

Kata kunci: Berpikir kritis; kecakapan abad 21; modul ajar; penelitian dan pengembangan.

\begin{abstract}
This research aims to develop a valid, practical, and effective technology-enhanced module in developing students' $21^{\text {st }}$ century skills in the topic of the circle. The present study employed a research and development method, namely the ADDIE model. The analysis phase includes an analysis of the needs of learning resources, curriculum, and materials. The design phase consisted of making modules, setting the layout, and searching reference books as well as designing assessment instruments. The development phase includes module development, expert validation, and module revision. The implementation phase produced a trial module for students that has been validated and revised. The evaluation phase is an evaluation of the module's strengths and weaknesses that have been tested. Module's quality is determined by three criteria, namely validity, practicality, and effectiveness. This module was rated as valid from material experts with an average of $87 \%$ and from media experts with an average of $83 \%$. In addition, this module was rated as practical based on the responses of respondents with an average of 74\%. Furthermore, based on the results of interviews with teachers, this module helps students understanding the circle and potentially can improve students' 21 st century skills. Based on these results, it can be concluded that the technology-enhanced module is valid, practical, and effective.
\end{abstract}

Keywords: $21^{\text {st }}$ century skills; critical thinking; instructional modules; research and development. 
DOI: https://doi.org/10.24127/ajpm.v9i3.2925

\section{PENDAHULUAN}

Abad 21 memberikan banyak peluang bagi dunia pendidikan untuk berkembang secara lebih cepat dibandingkan periode-periode waktu sebelumnya. Dengan adanya internet, siswa memiliki peluang yang sangat besar untuk melakukan kolaborasi dengan orang lain tanpa berada di tempat yang sama dan pada waktu yang bersamaan (Wahl \& Kitchel, 2016). Teknologi yang memberikan akses informasi yang begitu mudah juga memberikan dampak yang begitu besar bagi siswa untuk dapat berpikir dan bertindak secara kreatif dalam memecahkan permasalahannya (Jahnke \& Liebscher, 2020). Dengan berbagai peluang dan kemudahan ini, siswa dituntut untuk dapat mengolah informasi yang diterimanya secara kritis dan bijak (Eshet-Alkalai \& Geri, 2010).

Perkembangan yang ada dalam abad 21 menuntut sistem pendidikan untuk memikirkan kembali apa yang perlu dipelajari dan dikuasai oleh siswa. Menyikapi tantangan ini, Partnership for $21^{\text {st }}$ Century Skills (P21) merumuskan beberapa keterampilan definitif yang perlu dikuasai oleh siswa, salah satunya adalah keterampilanketerampilan belajar dan berinovasi (P21, 2019). Keterampilan-keterampilan belajar dan berinovasi ini ditujukan untuk menyiapkan siswa agar mereka siap dalam menghadapi situasi hidup dan lingkungan kerja yang kompleks. Keterampilan-keterampilan tersebut terdiri dari kreativitas dan inovasi, berpikir kritis dan pemecahan masalah, komunikasi, dan kolaborasi.

Keterampilan-keterampilan abad 21 yang didefinisikan oleh P21 tersebut sejalan dengan proses-proses matematis yang dikembangkan dalam pembelajaran matematika. Prosesproses matematis tersebut yaitu pemecahan masalah, penalaran dan pembuktian, komunikasi, koneksi, dan representasi (NCTM, 2000). Dengan desain aktivitas dan teknologi yang sesuai, pembelajaran matematika dapat digunakan untuk mengembangkan kecakapan abad 21 siswa (Bray \& Tangney, 2016). Desain aktivitas seperti ini dapat disematkan ke dalam berbagai jenis bahan ajar, salah satunya adalah modul ajar.

Modul ajar memiliki peran yang penting dalam mengembangkan kecakapan abad 21 siswa dalam pembelajaran matematika. Selain sebagai sumber belajar mandiri siswa (Febriana et al., 2020; Nurmeidina et al., 2020), modul ajar memiliki peran kunci dalam membantu guru mendesain pembelajarannya (Pepin et al., 2017a). Ketika desain aktivitas-aktivitas pembelajaran dalam suatu modul didasarkan pada pengembangan kecakapan abad 21, aktivitas-aktivitas tersebut akan potensial diterapkan dalam suatu pembelajaran.

Seiring semakin mudahnya akses teknologi bagi siswa (BPS, 2018), pengintegrasian teknologi ke dalam modul ajar berpeluang memperkaya pengalaman belajar siswa. Berbagai macam teknologi, misalnya media dinamis dan interaktif, dapat digunakan sebagai fitur tambahan dalam suatu modul ajar. Untuk konteks seperti ini, teknologi memberikan nilai tambah bagi modul ajar, yaitu sebagai penambah ruang penjelasan konten (Pepin et al., 2017b). Dengan kata lain, teknologi tersebut dapat digunakan untuk mengenalkan atau menjelaskan suatu topik tertentu secara lebih mendalam, dinamis, dan interaktif.

Meskipun banyak peluang yang diberikan oleh modul ajar berbasis kecakapan abad 21, tetapi tidak banyak sekolah yang sudah menggunakan 
modul seperti ini dalam pembelajaran matematika. Salah satunya adalah sebuah SMA swasta di Muntilan. Berdasarkan wawancara dengan guru bidang studi matematika ketika penelitian ini dilakukan, pembelajaran matematika di sekolah tersebut masih belum memanfaatkan modul yang berbasis kecakapan abad 21. Padahal beberapa penelitian menunjukkan bahwa bahan ajar jenis ini berpotensi efektif untuk meningkatkan kecakapan abad 21 siswa. Misalnya, penelitian yang dilakukan oleh Putri et. al. (2019) menunjukkan bahwa modul matematika yang dikembangkannya dapat mengembangkan kemampuan berpikir kritis matematis siswa jenjang SMA. Selain itu, beberapa penelitian lain juga telah menunjukkan bahwa modul ajar dapat digunakan sebagai bahan ajar yang efektif untuk meningkatkan kemampuan berpikir kreatif, komunikasi, dan kolaborasi siswa (Novalia \& Noer, 2019; Wijaya, 2017).

\section{Berdasarkan} pentingnya kecakapan abad 21, modul ajar, dan teknologi dalam pembelajaran matematika serta kebutuhan akan modul ajar yang berbasis kecakapan abad 21 di sekolah yang menjadi sasaran penelitian ini, tujuan penelitian ini adalah untuk mengembangkan modul ajar berbantuan teknologi berkualitas baik untuk mengembangkan kecakapan abad 21 siswa sebagai bahan ajar pembelajaran matematika di sekolah tersebut. Dengan demikian, proses pengembangan modul ajar berbantuan teknologi tersebut beserta dengan kualitasnya akan menjadi fokus pembahasan penelitian ini. Kualitas modul ajar yang dikembangkan diukur berdasarkan kriteria validitas, kepraktisan, dan efektivitasnya (Kristanto et al., 2016).

\section{METODE PENELITIAN}

Jenis penelitian yang digunakan dalam penelitian ini adalah penelitian dan pengembangan. Model pengembangan yang digunakan adalah model ADDIE (Branch, 2009). Produk yang dikembangkan dari penelitian ini adalah modul ajar cetak berbantuan teknologi pada materi lingkaran untuk mengembangkan kecakapan abad 21 siswa SMA. Subjek penelitian ini adalah siswa kelas XI MIPA di suatu sekolah swasta di Muntilan pada tahun ajaran 2019/2020 yang berjumlah 14 siswa.

Proses pengembangan modul tersebut mengikuti langkah-langkah model ADDIE, yaitu analisis (analysis), perancangan (design), pengembangan (development), dan implementasi (implementation). Tahap analisis dilakukan dengan tujuan untuk menganalisis perlunya pengembangan modul. Analisis yang dilakukan meliputi analisis kebutuhan sumber belajar, analisis kurikulum yaitu menentukan standar kompetensi, kompetensi dasar dan indikator pencapaian kompetensi yang sesuai dengan kurikulum 2013 serta analisis materi khususnya pada materi lingkaran.

Tahap desain dilakukan dengan tujuan merancang penulisan modul berdasarkan hasil dari tahap analisis. Kegiatan yang dilakukan yaitu: membuat kerangka penyusunan modul; menentukan tata letak modul; menentukan buku referensi yang berkaitan dengan materi lingkaran kelas $\mathrm{XI}$; dan menyusun instrumen penilaian modul.

Tahap pengembangan merupakan tahap untuk merealisasikan kerangka penyusunan modul yang telah dirancang. Selain itu pada tahap ini juga dilakukan validasi dan revisi modul 
agar modul yang dikembangkan dapat mencapai tujuan yang diharapkan.

Tahap keempat adalah tahap implementasi. Tahap ini bertujuan untuk melakukan uji coba modul yang telah divalidasi dan direvisi. Modul diujicobakan pada kelompok kecil (uji terbatas) yaitu pada siswa kelas XI MIPA di sebuah SMA swasta di Muntilan. Setelah uji coba modul, siswa diminta untuk memberikan tanggapannya terhadap modul tersebut dengan mengisi kuesioner. Kuesioner ini bertujuan untuk mendapatkan data kepraktisan modul.

Terakhir, tahap evaluasi dilakukan untuk menganalisis kelebihan dan kekurangan modul yang telah diujicoba. Tahapan analisis dilakukan berdasarkan hasil kuesioner respon siswa. Kegiatan ini menjadi sarana perbaikan dari proses pengembangan yang belum maksimal dikerjakan. Selain itu, proses evaluasi juga juga dilakukan di setiap tahapan lainnya agar menghasilkan modul ajar yang sesuai dengan tujuan penelitian.

Teknik pengumpulan data yang digunakan dalam penelitian ini adalah (1) wawancara tidak terstruktur untuk mengetahui hal-hal yang berkaitan dengan pembelajaran, antara lain sumber belajar matematika yang digunakan oleh guru dan siswa serta kesulitan belajar siswa khususnya terkait materi lingkaran pada matematika peminatan kelas XI MIPA; (2) wawancara terstruktur untuk mengetahui hal-hal yang berkaitan dengan efektivitas modul dalam proses pembelajaran yang ditinjau dari kegunaan dan potensinya untuk meningkatkan kecakapan abad 21; (3) penyebaran kuesioner digunakan untuk mengetahui kepraktisan modul yang dikembangkan; dan (4) validasi modul digunakan untuk mengukur validitas dari modul yang dikembangkan.
Validasi ini ditujukan kepada ahli materi dan ahli media.

Instrumen pengumpulan data dalam penelitian ini berupa pedoman wawancara, lembar validasi modul, dan lembar kuesioner respon siswa. Teknik analisis data pada penelitian ini adalah analisis validitas modul dan analisis kuesioner kepraktisan modul. Data validitas modul diperoleh berdasarkan hasil validasi modul yang telah dilakukan validator. Validasi modul diukur dengan menggunakan skala Likert empat skala, mulai dari 1, sangat tidak setuju, sampai 4, sangat setuju.

Skor yang telah diperoleh berdasarkan penilaian ahli kemudian diubah ke dalam persentase. Persentase ini dihitung dengan menggunakan rumus (1).

$$
V=\frac{\sum x}{\sum x i} \times 100 \%
$$

dengan $V$ adalah persentase validitas modul, $\Sigma x$ adalah jumlah keseluruhan penilaian ahli, dan $\Sigma x i$ adalah jumlah keseluruhan nilai ideal. Setelah hasil persentase diketahui, tingkat validitas modul yang dikembangkan kemudian dikelompokkan ke dalam kriteria validitas produk yang ditunjukkan pada Tabel 1.

Tabel 1. Kriteria validitas materi dan kriteria validitas media.

\begin{tabular}{lll}
\hline No & \multicolumn{1}{c}{$\begin{array}{c}\text { Kriteria } \\
\text { Validitas }\end{array}$} & $\begin{array}{c}\text { Tingkat } \\
\text { Validitas }\end{array}$ \\
\hline 1 & $85 \%<V \leq 100 \%$ & Sangat valid \\
2 & $70 \%<V \leq 85 \%$ & Valid \\
3 & $50 \%<V \leq 70 \%$ & Kurang valid \\
4 & $V \leq 50 \%$ & Tidak valid \\
\hline
\end{tabular}

Data kepraktisan modul diperoleh berdasarkan hasil kuesioner respon siswa. Hasil kuesioner diukur menggunakan skala Likert empat skala, 
yaitu sangat setuju, setuju, tidak setuju, dan sangat tidak setuju. Kuesioner respon siswa ini terdiri dari pernyataan positif dan pernyataan negatif. Untuk pernyataan positif, respon sangat setuju diberikan skor 4 dan seterusnya sampai respon sangat tidak setuju diberikan skor 1. Untuk pernyataan negatif, penskorannya kebalikan dari penskoran pernyataan positif. Skor kepraktisan modul dihitung dengan menggunakan rumus (2).

$$
P=\frac{\sum T S e}{\sum T S h} \times 100 \%
$$

dengan $P$ adalah persentase kepraktisan modul, $T S e$ adalah jumlah skor respon semua siswa, dan TSh adalah jumlah skor maksimal yang mungkin dari respon semua siswa. Setelah hasil diketahui, hasil tersebut kemudian dikelompokkan ke dalam kriteria kepraktisan produk. Kriteria kepraktisan produk disajikan pada Tabel 2.

Tabel 2. Kriteria kepraktisan produk.

\begin{tabular}{|c|c|c|}
\hline No & $\begin{array}{c}\text { Kriteria } \\
\text { Kepraktisan }\end{array}$ & $\begin{array}{c}\text { Tingkat } \\
\text { Kepraktisan }\end{array}$ \\
\hline 1 & $80 \%<P \leq 100 \%$ & Sangat Praktis \\
\hline 2 & $60 \%<P \leq 80 \%$ & Praktis \\
\hline 3 & $40 \%<P \leq 60 \%$ & $\begin{array}{l}\text { Kurang } \\
\text { Praktis }\end{array}$ \\
\hline 4 & $20 \%<P \leq 40 \%$ & Tidak Praktis \\
\hline 5 & $0<P \leq 20 \%$ & $\begin{array}{l}\text { Sangat Tidak } \\
\text { Praktis }\end{array}$ \\
\hline
\end{tabular}

\section{HASIL DAN PEMBAHASAN}

\section{Proses Pengembangan Modul}

Penelitian ini menghasilkan produk berupa modul ajar berbantuan teknologi pada materi lingkaran untuk mengembangkan kecakapan abad 21 siswa. Pengembangan modul tersebut mengikuti lima tahapan dalam model ADDIE. Secara rinci, tahapan-tahapan yang dilakukan adalah sebagai berikut.

\section{Analisis (Analysis)}

Analisis kebutuhan sumber belajar dilakukan berdasarkan hasil wawancara. Berdasarkan hasil wawancara dengan guru matematika peminatan kelas XI MIPA di SMA yang menjadi sasaran penelitian ini, diperoleh informasi bahwa dalam pembelajaran guru dan siswa menggunakan buku matematika kurikulum 2013 dari penerbit swasta. Buku tersebut dianggap belum mengarah pada kecapakan abad 21 karena secara ekplisit kurang berfokus pada pengembangan keterampilan berpikir kreatif, berpikir kritis, komunikasi, dan kolaborasi. Selain itu, guru juga belum pernah menyusun bahan ajar berupa modul siswa untuk meningkatkan kecakapan abad 21 yang memuat aspek-aspek berpikir kritis, berpikir kreatif, kolaborasi, dan komunikasi. Selain itu, analisis kurikulum juga dilakukan untuk mengetahui kurikulum yang digunakan serta untuk mengidentifikasi kompetensi dasar dan merumuskan indikator pencapaian kompetensi yang sesuai dengan Kurikulum 2013. Materi yang dimuat adalah materi lingkaran dengan sub pokok bahasan persamaan lingkaran, kedudukan titik dan garis terhadap lingkaran, serta garis singgung lingkaran.

\section{Perancangan (Design)}

Pembuatan kerangka penyusunan modul berdasarkan panduan penyusunan bahan ajar dari Ristekdikti tahun 2017 yang meliputi pendahuluan; deskripsi singkat, relevansi dan capaian pembelajaran, penyajian; uraian materi, contoh soal, latihan soal, aktivitas interaktif, gambar, rangkuman, dan penutup; tes formatif, kunci jawaban, dan daftar pustaka. Pada tahap ini juga dilakukan pemilihan buku referensi serta penyusunan instrumen penilaian 
modul matematika yang terdiri dari lembar validasi modul untuk ahli materi dan ahli media, lembar kuesioner respon siswa serta pedoman wawancara.

\section{Pengembangan (Development)}

Modul yang dikembangkan secara garis besar mencakup uraian materi yang mengarah pada kecakapan abad 21, yaitu berpikir kritis, berpikir kreatif, komunikasi dan kolaborasi; aktivitas interaktif berbasis teknologi (Chan \& Leung, 2014); dan video pembelajaran (Morain \& Swarts, 2012).

Modul tersebut kemudian divalidasi oleh para ahli, yaitu ahli materi dan ahli media. Dari segi materi, aspek yang dinilai meliputi aspek kelayakan isi, kelayakan penyajian, dan kelayakan bahasa. Dari segi media, aspek yang dinilai meliputi aspek kelayakan kegrafikan dan media elektronik.

Proses validasi tersebut menghasilkan beberapa kritik dan saran dari para ahli. Kritik dan saran dari ahli materi dan media antara lain (1) materi cenderung diberikan, baik jika siswa menemukan sendiri; (2) menambahkan permasalahan yang mampu menggali critical dan creative thinking; (3) memperbaiki penulisan daftar pustaka; (4) menambahkan skor penilaian pada tes formatif; (5) memperpendek tautan URL dan (6) memperbaiki kode QR agar dapat diakses. Semua kritik dan saran tersebut digunakan untuk merevisi modul ajar yang dikembangkan.

\section{Implementasi (Implementation)}

Pada tahap implementasi dilakukan uji coba modul yang telah divalidasi dan direvisi. Uji coba ini dimaksudkan untuk melihat tingkat kepraktisan modul. Uji coba modul matematika dilakukan pada siswa kelas XI MIPA sebuah SMA swasta di
Muntilan tahun pelajaran 2019/2020 yang berjumlah 14 siswa. Setelah menggunakan modul, siswa kemudian diminta untuk mengisi kuesioner. Kuesioner ini bertujuan untuk melihat respon siswa terhadap modul yang telah dikembangkan ditinjau dari beberapa aspek yaitu kemudahan, daya tarik dan efisiensi. Selanjutnya, efektivitas modul dilihat berdasarkan hasil wawancara dengan guru mata pelajaran matematika peminatan, yang meliputi manfaat penggunaan modul, penilaian modul dan fungsi modul, serta hasil pengerjaan siswa pada modul tersebut.

\section{Evaluasi (Evaluation)}

Modul yang telah diujicoba kemudian dianalisis kelebihan dan kekurangannya. Analisis modul dilakukan berdasarkan hasil kuesioner respon siswa. Kelebihan-kelebihan modul matematika yang dikembangkan antara lain: (1) materi dan contoh soal pada modul yang dikembangkan ringkas dan mudah dipahami; (2) modul yang dikembangkan menarik untuk dibaca dan mendorong untuk melakukan diskusi dengan teman; dan (3) dapat membantu mempelajari materi lingkaran. Sedangkan kekurangan pada modul ini yaitu bahasa dan kalimat yang digunakan masih sulit untuk dimengerti.

\section{Kualitas Modul}

Kualitas modul ajar yang dikembangkan dianalisis berdasarkan validitas, kepraktisan, dan efektivitas modul tersebut (Kristanto et al., 2016). Hasil analisis berdasarkan masingmasing kriteria ini selanjutnya dipaparkan sebagai berikut.

\section{Validitas modul}

Validitas modul yang

dikembangkan didasarkan pada hasil penilaian yang dilakukan oleh para ahli. 
Hasil penilaian dari ahli materi pada aspek kelayakan isi diperoleh persentase validitas sebesar 79\%, sedangkan pada aspek kelayakan penyajian dan bahasa secara berturut-turut diperoleh persentase validitas sebesar $93 \%$ dan $90 \%$. Skor rata-rata ketiga aspek tersebut adalah 87\%. Oleh karena itu, dari segi materi, modul yang telah dikembangkan sangat valid. Data analisis validasi modul dari ahli materi dapat dilihat pada Tabel 3 .
Selanjutnya, hasil penilaian dari ahli media pada aspek kelayakan kegrafikan didapatkan persentase validitas sebesar 91\% dan pada aspek kelayakan media elektronik didapatkan persentase validitas sebesar 75\%. Dari kedua aspek tersebut diperoleh skor rata-rata yaitu $83 \%$. Oleh karena itu, dari segi media, modul yang telah dikembangkan valid. Data analisis validasi modul dari ahli media dapat dilihat pada Tabel 4.

Tabel 3. Hasil validasi ahli materi.

\begin{tabular}{cccc}
\hline No & Aspek & Persentase & Kriteria \\
\hline 1 & Kelayakan Isi & $79 \%$ & Valid \\
2 & Kelayakan Penyajian & $93 \%$ & Sangat Valid \\
3 & Kelayakan Bahasa & $90 \%$ & Sangat Valid \\
& Rata-rata & $87 \%$ & Sangat Valid \\
\hline
\end{tabular}

Tabel 4. Hasil validasi ahli media.

\begin{tabular}{cccc}
\hline No & Aspek & Persentase & Kriteria \\
\hline 1 & Kelayakan Kegrafikaan & $91 \%$ & Sangat Valid \\
2 & Kelayakan Media Elektronik & $75 \%$ & Valid \\
& Rata-rata & $83 \%$ & Valid \\
\hline
\end{tabular}

2. Kepraktisan modul

Kepraktisan modul yang dikembangkan dianalisis berdasarkan hasil kuesioner respon siswa. Kepraktisan modul ditinjau dari aspek kemudahan penggunaan, daya tarik, dan efisiensi. Pada aspek kemudahan penggunaan diperoleh persentase sebesar $71 \%$, pada aspek daya tarik diperoleh persentase sebesar $75 \%$, dan pada aspek efisiensi diperoleh persentase sebesar 75\%. Dari ketiga aspek tersebut diperoleh skor rata-rata persentase sebesar 74\%. Oleh karena itu, dapat disimpulkan bahwa modul yang dikembangkan praktis untuk digunakan oleh siswa. Perbandingan persentase kepraktisan modul pada setiap aspek disajikan pada Gambar 1 .

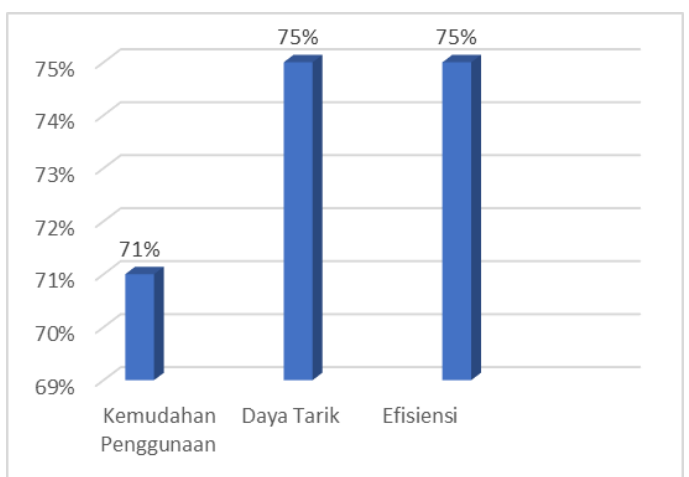

Gambar 1. Diagram kepraktisan modul. 
DOI: https://doi.org/10.24127/ajpm.v9i3.2925

Kepraktisan modul ini menunjukkan bahwa modul tersebut mudah digunakan oleh siswa, memiliki daya tarik, dan efisien. Kemudahan penggunaan tersebut merujuk pada seberapa baik organisasi materi dan teknologi yang digunakan dalam modul tersebut. Organisasi materi tersebut merupakan elemen penting dalam memfasilitasi pembelajaran siswa (Zhao \& Sullivan, 2017). Selain itu, penerimaan siswa terhadap teknologi yang digunakan dalam modul juga akan mempengaruhi seberapa baik siswa akan belajar (Shieh \& Yu, 2016).

Daya tarik modul berkaitan dengan motivasi belajar siswa. Ketika motivasi siswa tinggi, maka siswa tersebut memiliki kecenderungan untuk mendapatkan hasil belajar yang optimal, termasuk dalam pembelajaran matematika (Murayama et al., 2013). Lebih jauh, motivasi belajar siswa memiliki posisi yang penting agar siswa tersebut dapat belajar secara mandiri (George, 2012). Dengan demikian, daya tarik yang dimiliki oleh modul dalam penelitian ini akan memfasilitasi siswa untuk mempelajari materi secara mandiri dengan baik. Hal ini dikuatkan juga oleh efisiensi modul dalam penelitian ini yang masuk dalam kategori baik.

\section{Efektivitas modul}

Efektivitas modul yang dikembangkan dianalisis berdasarkan hasil wawancara yang dilakukan dengan guru mata pelajaran matematika peminatan kelas XI MIPA dan didukung dengan hasil pengerjaan siswa terhadap aktivitas-aktivitas dalam modul. Dari hasil wawancara diketahui bahwa modul yang dikembangkan dapat "membantu siswa dalam belajar mandiri, dan modul ini memberi motivasi siswa untuk lebih banyak berlatih memecahkan persoalan matematika tentang persamaan lingkaran secara mandiri di rumah". Selain itu, guru mengaku bahwa modul yang dikembangkan juga sudah mencakup kecakapan abad 21 dan dapat berpotensi meningkatkan kecakapan abad 21 siswa karena di dalam modul terdapat bagian-bagian yang menuntun siswa untuk berpikir kritis, kreatif, komunikasi, dan kolaborasi. Hasil wawancara dari guru tersebut diperkuat dengan contoh hasil pengerjaan siswa yang ditunjukkan pada Gambar 2 . Pengerjaan tersebut menunjukkan bahwa aktivitas pembelajaran yang disediakan di modul ajar telah memfasilitasi siswa untuk berkolaborasi dan berpikir kritis.

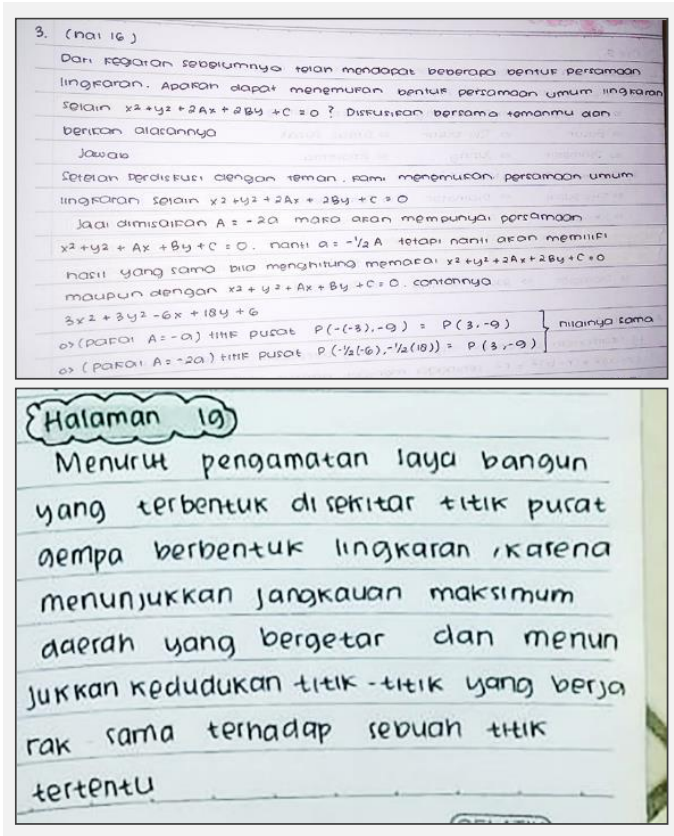

Gambar 2. Hasil pengerjaan siswa.

Berdasarkan hasil wawancara dari guru yang diperkuat dengan contoh hasil pengerjaan siswa, dapat disimpulkan bahwa modul yang dikembangkan berpotensi efektif untuk membantu siswa memahami materi lingkaran khususnya topik persamaan lingkaran dan memiliki potensi untuk 
meningkatkan kecakapan abad 21. Hal ini sejalan dengan penelitian Utami et al. (2018) yang menyatakan bahwa modul dapat membantu siswa untuk menemukan konsep pemahaman matematika dengan mudah.

Modul ajar sebagai produk penelitian ini tersedia secara terbuka di https://doi.org/10.6084/m9.figshare. 127 57982. Modul tersebut memuat fiturfitur Ayo Berpikir Kritis, Ayo Berkomunikasi, Ayo Berpikir Kreatif, Ayo Berkolaborasi, dan berbagai fitur teknologi. Contoh fitur Ayo Berpikir Kritis ditunjukkan pada Gambar 3. Contoh tersebut mengajak siswa untuk secara kritis memikirkan persamaan alternatif dari lingkaran. Fitur tersebut ditujukan untuk membantu siswa agar lebih bisa memahami konsep matematika yang sedang dipelajari melalui proses pemaknaan, analisis, evaluasi, dan penyajian gagasan/ide matematis secara logis (Chukwuyenum, 2013).

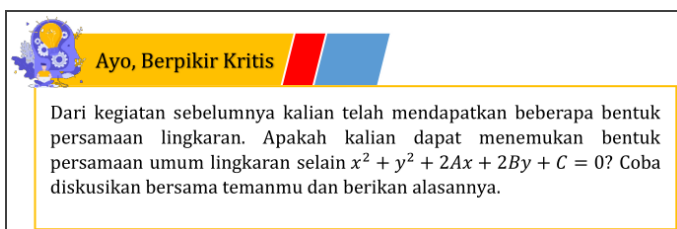

Gambar 3. Contoh fitur Ayo Berpikir Kritis

Contoh fitur Ayo Berkomunikasi ditunjukkan pada Gambar 4. Dalam contoh tersebut, siswa didorong untuk menyampaikan gagasan matematisnya mengenai garis singgung lingkaran kepada teman-temannya. Selain itu, melalui aktivitas tersebut siswa juga didorong untuk menganalisis dan mengevaluasi gagasan atau pemikiran matematis teman-temannya.

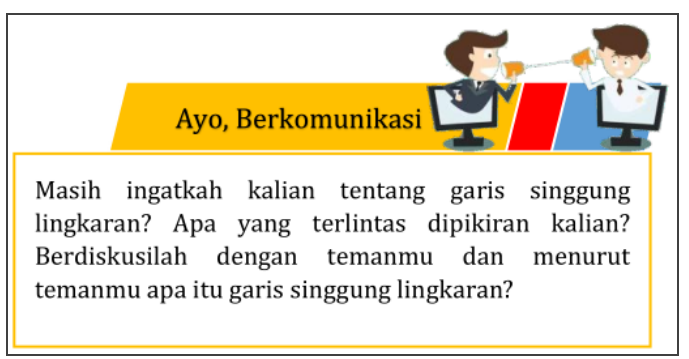

Gambar 4. Contoh fitur Ayo

Berkomunikasi

Gambar 5 menunjukkan contoh fitur Ayo Berpikir Kreatif yang terdapat dalam modul ajar yang dikembangkan. Contoh tersebut menunjukkan bagaimana aktivitas yang dikembangkan dalam modul tersebut memfasilitasi siswa untuk menyelesaikan permasalahan yang diberikan dengan menggunakan pemikiran masing-masing. Permasalahan tersebut memfasilitasi siswa untuk menyediakan penyelesaian yang berbeda-beda.

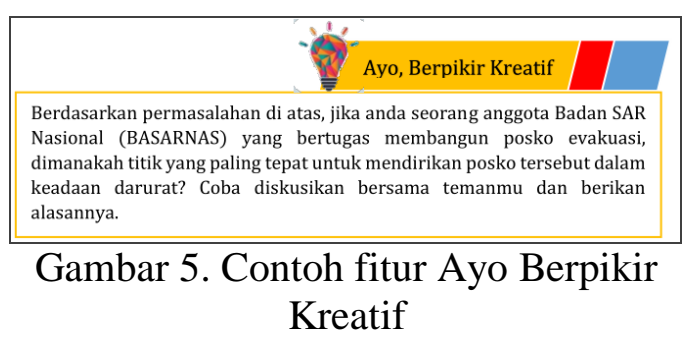

Gambar 6 menunjukkan contoh fitur Ayo Berkolaborasi. Contoh tersebut mendorong siswa untuk berdiskusi dengan teman-temannya agar permasalahan yang diberikan dapat diselesaikan. Aktivitas kolaboratif terstruktur seperti ini dapat memfasilitasi siswa untuk berinteraksi secara efektif dengan orang lain, misalnya menanya, memberikan umpan balik, memberikan saran, dan membagikan ide (Chen \& Chiu, 2016; $\underline{\text { Kristanto, 2018). }}$. 
DOI: https://doi.org/10.24127/ajpm.v9i3.2925

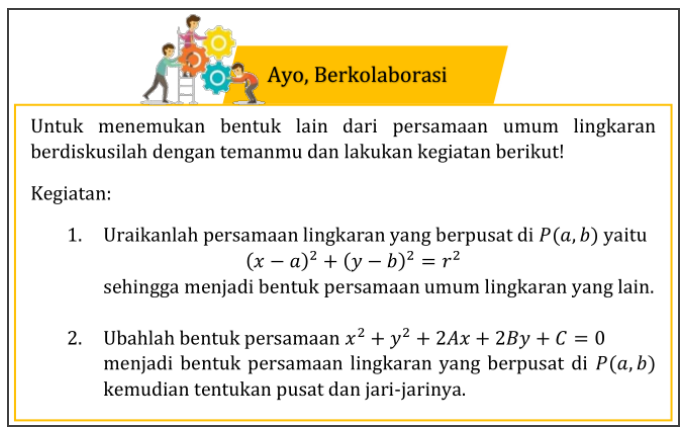

Gambar 6. Contoh fitur Ayo Berkolaborasi

Modul yang dikembangkan juga memuat berbagai fitur teknologi. Teknologi yang digunakan antara lain video pembelajaran, simulasi, dan kuis daring. Integrasi teknologi ke dalam modul dilakukan dengan menggunakan tautan singkat dan kode QR. Contoh integrasi teknologi ke dalam modul ditunjukkan pada Gambar 7.

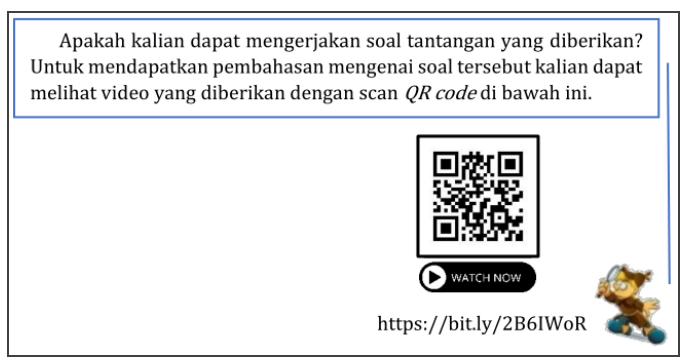

Gambar 7. Contoh integrasi teknologi ke dalam modul ajar

Modul yang dikembangkan dalam penelitian ini memiliki dampak praktis dan teoretis. Secara praktis, modul tersebut dapat digunakan oleh guru untuk memfasilitasi siswa jenjang SMA dalam pembelajaran topik lingkaran melalui aktivitas-aktivitas yang mendorong berkembangnya keterampilan-keterampilan berpikir kreatif, berpikir kritis, berkomunikasi, dan berkolaborasi. Lebih lanjut, modul tersebut dapat digunakan oleh siswa untuk belajar secara mandiri karena, seperti modul-modul pada umumnya, modul tersebut menyediakan pembahasan materi dan rangkumannya, contoh-contoh soal, latihan-latihan yang bervariasi, serta tes dan kunci jawabannya. Secara teoretis, proses pengembangan modul yang dipaparkan dalam artikel ini dapat digunakan sebagai salah satu rujukan untuk mengembangkan perangkat ajar dengan jenis dan tujuan yang serupa.

\section{KESIMPULAN DAN SARAN}

Dari hasil penelitian dan pengembangan modul ajar berbantuan teknologi yang memiliki kualitas baik untuk mengembangkan kecakapan abad 21 siswa. Dengan kata lain, modul yang dikembangkan dalam penelitian ini telah valid, praktis, dan efektif. Berdasarkan penilaian ahli materi dan media, modul tersebut secara berturutturut memiliki rata-rata skor validitas $87 \%$ (sangat valid) dan $83 \%$ (valid). Berdasarkan penilaian dari siswa, kepraktisan modul tersebut memiliki skor rata-rata $74 \%$ sehingga disimpulkan bahwa modul tersebut praktis. Terakhir, berdasarkan penilaian guru dan didukung dengan hasil pengerjaan siswa, modul yang dikembangkan juga efektif.

Meskipun modul ini sudah melalui tahapan validasi dan uji coba, perlu diakui bahwa pengembangan modul tersebut masih memiliki keterbatasan. Kesimpulan mengenai validitas, kepraktisan, dan efektivitas modul tersebut dalam mengembangkan kecakapan abad 21 siswa masih terbatas pada subjek penelitian ini dan konteksnya. Oleh karena itu, disarankan bagi peneliti lain untuk menyelidiki pengaruh modul tersebut terhadap kecakapan abad 21 siswa dengan menggunakan desain penelitian yang berbeda, misalkan penelitian eksperimen, dan dengan subjek penelitian yang lebih banyak. 
DOI: https://doi.org/10.24127/ajpm.v9i3.2925

\section{UCAPAN TERIMA KASIH}

Kami mengucapkan terima kasih kepada guru dan semua siswa yang telah membantu penelitian ini, serta kepada Maria Suci Apriani, S.Pd., M.Sc. dan Margaretha Madha Melissa, S.Pd., M.Pd. yang telah bersedia memvalidasi modul yang kami kembangkan.

\section{DAFTAR PUSTAKA}

BPS. (2018). Penggunaan dan Pemanfaatan Teknologi Informasi dan Komunikasi (P2TIK) Sektor Pendidikan 2018. BPS RI.

Branch, R. M. (2009). Instructional Design: The ADDIE Approach. Springer US. https://doi.org/10.1007/978-0-387$\underline{\text { 09506-6 }}$

Bray, A., \& Tangney, B. (2016). Enhancing student engagement through the affordances of mobile technology: a 21 st century learning perspective on Realistic Mathematics Education. Mathematics Education Research Journal, 28(1), 173-197. https://doi.org/10.1007/s13394015-0158-7

Chan, K. K., \& Leung, S. W. (2014). Dynamic Geometry Software Improves Mathematical Achievement: Systematic Review and Meta-Analysis. Journal of Educational Computing Research, 51(3), 311-325. https://doi.org/10.2190/EC.51.3.c

Chen, C.-H., \& Chiu, C.-H. (2016). Collaboration Scripts for Enhancing Metacognitive Selfregulation and Mathematics Literacy. International Journal of Science and Mathematics
Education, 14(2), 263-280. https://doi.org/10.1007/s10763015-9681-y

Chukwuyenum, A. N. (2013). Impact of Critical Thinking on Performance in Mathematics Among Senior Secondary School Students in Lagos State. IOSR Journal of Research \& Method in Education, 3(5), 18-25.

Eshet-Alkalai, Y., \& Geri, N. (2010). Does the medium affect the message? The effect of congruent versus incongruent display on critical reading. Human Systems Management, 29(4), 243-251. https://doi.org/10.3233/HSM$\underline{2010-0730}$

Febriana, R., Yusri, R., \& Delyana, H. (2020). Modul Geometri Ruang Berbasis Problem Based Learning Terhadap Kreativitas Pemecahan Masalah. AKSIOMA: Jurnal Program Studi Pendidikan Matematika, 9(1), 93-100. https://doi.org/10.24127/ajpm.v9i1. $\underline{2591}$

George, M. (2012). Autonomy and Motivation in Remedial Mathematics. PRIMUS, 22(4), 255-264.

https://doi.org/10.1080/10511970.2 $\underline{010.497958}$

Jahnke, I., \& Liebscher, J. (2020). Three types of integrated course designs for using mobile technologies to support creativity in higher education. Computers \& Education, 146, 103782. https://doi.org/10.1016/j.compedu. $\underline{2019.103782}$ 
Kristanto, Y. D. (2018). Technologyenhanced pre-instructional peer assessment: Exploring students' perceptions in a Statistical Methods course. REiD (Research and Evaluation in Education), 4(2), 105-116. https://doi.org/10.21831/reid.v4i2. $\underline{20951}$

Kristanto, Y. D., Amin, S. M., \& Khabibah, S. (2016). The Development of Investigative Learning Materials Using Computer Assisted Instruction in the Topic of Reflection for Grade VII. Journal of Research and Advances in Mathematics Education, 1(2), 172-182. https://doi.org/10.23917/jramathed u.v1i2.4828

Morain, M., \& Swarts, J. (2012). YouTutorial: A Framework for Assessing Instructional Online Video. Technical Communication Quarterly, 21(1), 6-24. https://doi.org/10.1080/10572252.2 $\underline{012.626690}$

Murayama, K., Pekrun, R., Lichtenfeld, S., \& vom Hofe, R. (2013). Predicting Long-Term Growth in Students' Mathematics Achievement: The Unique Contributions of Motivation and Cognitive Strategies. Child Development, 84(4), 1475-1490. https://doi.org/10.1111/cdev.12036

NCTM. (2000). Principles and Standards for School Mathematics. The National Council of Teachers of Mathematics, Inc.

Novalia, H., \& Noer, S. H. (2019). Pengembangan Modul Pembelajaran Matematika dengan Strategi PQ4R untuk
Meningkatkan Kemampuan Berpikir Kreatif dan Kemandirian Belajar Siswa SMA. Jurnal Penelitian Dan Pembelajaran Matematika, 12(1), 51-65. https://doi.org/10.30870/jppm.v12i $\underline{1.4854}$

Nurmeidina, R., Lazwardi, A., \& Ariyanti, I. (2020). Pengembangan Modul Teori Peluang untuk Meningkatkan Hasil Belajar dan Disposisi Matematis. AKSIOMA: Jurnal Program Studi Pendidikan Matematika， 9(2), 440-450. https://doi.org/10.24127/ajpm.v9i2. $\underline{2824}$

P21. (2019). Framework for 21st Century Learning. https://www.battelleforkids.org/net works/p21/frameworks-resources

Pepin, B., Gueudet, G., \& Trouche, L. (2017). Refining teacher design capacity: Mathematics teachers' interactions with digital curriculum resources. ZDM, 49(5), 799-812. https://doi.org/10.1007/s11858017-0870-8

Pepin, B., Choppin, J., Ruthven, K., \& Sinclair, N. (2017). Digital curriculum resources in mathematics education: foundations for change. ZDM, 49(5), 645-661. https://doi.org/10.1007/s11858017-0879-z

Putri, D. A., Fitraini, D., \& Revita, R. (2019). Pengembangan Modul Matematika berbasis REACT untuk Memfasilitasi Kemampuan Berpikir Kritis Matematis Siswa SMA. JURING (Journal for Research in Mathematics Learning), 2(4), 345-356. 
DOI: https://doi.org/10.24127/ajpm.v9i3.2925

Shieh, C.-J., \& Yu, L. (2016). A Study on Information Technology Integrated Guided Discovery Instruction towards Students' Learning Achievement and Learning Retention. EURASIA Journal of Mathematics, Science and Technology Education, 12(4), 833-842.

https://doi.org/10.12973/eurasia.20 $\underline{15.1554 \mathrm{a}}$

Utami, T. N., Jatmiko, A., \& Suherman, S. (2018). Pengembangan Modul Matematika dengan Pendekatan Science, Technology, Engineering, And Mathematics (STEM) pada Materi Segiempat. Desimal: Jurnal Matematika, $\quad$ I(2), $\quad$ 165-172. https://doi.org/10.24042/djm.v1i2. $\underline{2388}$

Wahl, L., \& Kitchel, A. (2016). Internet Based Collaboration Tools. International Journal of ECollaboration, 12(1), 27-43. https://doi.org/10.4018/IJeC.20160 $\underline{10103}$
Wijaya, A. P. (2017). Pengembangan Modul Dengan Pendekatan Open Ended untuk Memfasilitasi Pencapaian Literasi Matematis. AKSIOMA: Jurnal Program Studi Pendidikan Matematika, 6(2), 159-168.

https://doi.org/10.24127/ajpm.v6i2. $\underline{996}$

Zhao, H., \& Sullivan, K. P. H. (2017). Teaching presence in computer conferencing learning environments: Effects on interaction, cognition and learning uptake. British Journal of Educational Technology, 48(2), 538-551. https://doi.org/10.1111/bjet.12383 